\title{
EFFECTS OF VARIOUS HELICALLY ANGLED GRINDING WHEELS ON THE SURFACE ROUGHNESS AND ROUNDNESS IN GRINDING CYLINDRICAL SURFACES
}

\author{
VPLIV RAZLIČNIH KOTOV VIJAČNICE PRI BRUSILNIH \\ KOLUTIH NA HRAPAVOST POVRŠINE IN OKROGLOST PRI \\ BRUŠENJU VALJASTIH POVRŠIN
}

\author{
Muammer Gavas ${ }^{1}$, Muammer Kına ${ }^{2}$, Ŭur Köklü ${ }^{3}$ \\ ${ }^{1}$ Department of Manufacturing Engineering, Dumlupinar University, Kütahya, Turkey \\ 2Istanbul Arel University, Istanbul, Turkey \\ ${ }^{3}$ Department of Mechanical Engineering, Karamanoglu Mehmetbey University, Karaman, Turkey \\ ugurkoklu@gmail.com
}

Prejem rokopisa - received: 2014-04-07; sprejem za objavo - accepted for publication: 2015-01-05

doi: $10.17222 /$ mit. 2014.065

\begin{abstract}
Grinding is generally used in the final step of machining metallic materials to achieve the necessary surface quality and dimensions. Grinding wheels with flat surfaces are commonly used in the process of grinding. However, due to the fact that there is a great deal of contact length (corresponding to the grinding-wheel width) between the grinding wheel and the workpiece, effective cooling during the grinding process may not be possible and, consequently, the heat in the deformation region is increased. Due to these reasons, some undesired results such as an unqualified surface and a roundness error take place. Various profiles of the grinding wheel were, therefore, proposed to improve the surface quality and decrease the roundness error by modifying the grinding wheel and developing various methods. In this study, AISI 1050, AISI 4140 and AISI 7131 steel materials were subjected to the cylindrical-grinding process using wheels helically grooved at $15^{\circ}, 30^{\circ}$ and $45^{\circ}$ and the obtained results such as the average surface roughness and roundness errors were compared with the results of the flat-surface grinding wheels. The experimental results show that the surface roughness and roundness error are reduced when using a helically grooved grinding wheel and, thus, the quality of the machined parts is improved.

Keywords: cylindrical grinding, helically grooved grinding wheel, roundness error, surface roughness
\end{abstract}

Brušenje se navadno uporablja kot končna stopnja obdelave kovinskih materialov za zagotovitev kvalitete površine in mer. Pri postopku brušenja se navadno uporabljajo brusni koluti z ravno površino. Vendar pa je zaradi velike kontakne dolžine (odvisno od širine brusilnega koluta) med brusilnim kolutom in obdelovancem oteženo učinkovito ohlajanje, zato se področje deformacije ogreva. Lahko se pojavijo neželeni rezultati, kot so neustrezna površina in napaka okroglosti. Za izboljšanje kvalitete površine in zmanjšanje napak okroglosti so predlagani modificirani brusilni koluti z različnimi profili in različne metode. V tej študiji so bila jekla AISI 1050, AISI 4140 in AISI 7131 okroglo brušena s koluti z vijačnim utorom $15^{\circ}, 30^{\circ}$ in $45^{\circ}$. Dobljeni rezultati, kot sta povprečna hrapavost površine in napaka okroglosti, so bili primerjani s tistimi, dobljenimi z brusilnimi koluti z ravno površino. Rezultati kažejo, da se površinska hrapavost in napaka okroglosti zmanjšujeta pri uporabi brusilnih kolutov z vijačnim utorom, torej se kvaliteta strojnih delov izboljša.

Ključne besede: okroglo brušenje, brusni kolut z vijačnim utorom, napaka okroglosti, hrapavost površine

\section{INTRODUCTION}

A better surface quality and higher efficiency are the prerequisites for today's machining industry in order for it to be more competitive since modern manufacturing processes require shorter production time and higherprecision components. ${ }^{1}$ Compared with the other material-removal processes such as turning, milling and boring, the grinding process is more complex and more difficult to control. ${ }^{2}$ Grinding is a finishing process, broadly used in the manufacturing of the components requiring fine tolerances, a good surface finish and a higher dimensional and geometrical accuracy. ${ }^{3,4}$ In spite of all the good results of this finishing process, there are some phenomena that affect the results. These are the chattering and vibration of the machine and workpiece, burning, unacceptable changes in the surface layer, and microcracks and burns that cause surface defects, in- creasing the surface roughness and other defects. These defects are caused by clamping the workpiece, the course and magnitude of the grinding-wheel wear, and the stiffness of the whole machine-tool/workpiece fixture system. ${ }^{5,6}$

The effects of a discontinuous workpiece material on the grinding performance were investigated by researchers. ${ }^{7,8}$ To control and improve the grinding performance we would have to manufacture engineered grinding wheels with a desirable topography to optimize the metal-cutting process. One example of such a design is a grooved wheel. ${ }^{9}$ Several studies confirmed that intermittent grinding not only decreases the grinding force, specific energy, surface burn, waviness and temperature but also optimizes the material-removal rate. ${ }^{10-12} \mathrm{Fan}$ and Miller ${ }^{12}$ developed a force model for grinding with segmental wheels. Both experimental and analytical results 
show that the average grinding force decreases and the peak force increases due to segmental wheels, as compared to conventional wheels. Larger spaces between the segments further reduce the average force and increase the surface roughness and peak force. Kim et al. ${ }^{13}$, Jin and Meng ${ }^{14}$ constructed discontinuous grinding wheels (DGWs) with multi-porous grooves. Their study illustrated that DGWs significantly improved the grinding performance and surface roughness.

Shaji and Radhakrishnan ${ }^{15}$ used slotted wheels with graphite integrated into the slots. Three such wheels were developed with a varying number of the slots for lubricant sandwiching. The results showed that the surface roughness and residual stress were lower in the case of the graphite-slotted wheels. The results of the experiments with helically grooved wheels grinding four different materials were reported by Gavas et al..$^{5}$ Their study illustrated that the ground-surface roughness decreased for some materials in comparison to the conventional grinding. The roundness slightly increased for brass and AISI 1010, but did not change for the AISI 1040 and AISI 2080 steels. Zhang ${ }^{16}$ conducted helical scan grinding (HSG) on brittle materials such as ceramics and glass, and ductile materials such as steel. The experimental results showed that HSG not only improved the ground-surface finish, but also decreased the adhesion of the workpiece material to the cutting grits in the grinding of tough materials such as stainless steel SUS304, and the fracture area in the grinding of brittle materials such as ceramics.

Zhang and Uematsu ${ }^{17}$ analytically studied this topic to find the difference in the surface-generation mechanism between HSG and traverse grinding, and they proposed models for predicting the surface roughness in HSG. Both the experimental results and analysis show that the ground-surface roughness decreases with the helix angle and reaches the limiting surface-roughness value at the critical helix angle, which is dependent on the speed ratio. The HSG method is more effective in improving the ground-surface roughness for large and/or coarse wheels than for small and/or fine wheels. Recently, Nguyen and Zhang ${ }^{18}$ investigated the performance of a segmented-grinding-wheel system and succeeded to maintain the sharpness of the active cutting edges while minimizing the ploughing and rubbing deformations of ground workpieces.

Using the intermittent grinding wheels, the characteristics of the grinding force, temperature, surface roughness and geometric error were evaluated by Kwak and Ha. ${ }^{19}$ With the results of the experiments with conventional and intermittent wheels, it was proven that the intermittent wheel appeared to be superior in various aspects such as the grinding force, the temperature and the geometric error, showing little deterioration of the surface roughness. Tawakoli and Azarhoushang ${ }^{20}$ investigated the feasibility of intermittent grinding with a segmented wheel, using two ceramic-matrix composite ma- terials. The grinding forces, surface roughness, surface profile, elastic deformation and tool wear were compared when grinding the ceramic-matrix composites with segmented and normal diamond wheels. The finer surface roughness obtained with the conventional grinding, compared to the intermittent grinding with a T-tool wheel, was due to a higher number of active cutting edges and more rubbing in the process.

In this paper, the results of the grinding experiments with helically grooved wheels used on three materials are presented and compared with those obtained with the conventional method. The grinding experiments were conducted on the AISI 1050, AISI 4140 and AISI 7131 steel materials, with three helically grooved grinding wheels. The surface roughness and roundness were studied as the performance criteria and better results were achieved when using the wheels helically grooved at $15^{\circ}$ and $30^{\circ}$ than a flat-surface wheel.

\section{EXPERIMENTAL PROCEDURE}

\subsection{Preparation of helically grooved grinding wheels}

The grinding tests were performed on a horizontal spindle-type cylindrical-grinding machine with four aluminum-oxide grinding wheels. All the wheels used in the experiments had the same specifications. However, one of the grinding wheels had a flat surface. This type is called the flat-surface grinding wheel (FSGW). The other grinding wheels with different helix angles were manufactured for this study. These types are called helically grooved grinding wheels with angles of $15^{\circ}$ (HGGW $15^{\circ}$ ), $30^{\circ}\left(\mathrm{HGGW} 30^{\circ}\right.$ ), and $45^{\circ}\left(\mathrm{HGGW} 45^{\circ}\right.$ ).

Figure 1 shows schematic drawings of the dimensions of

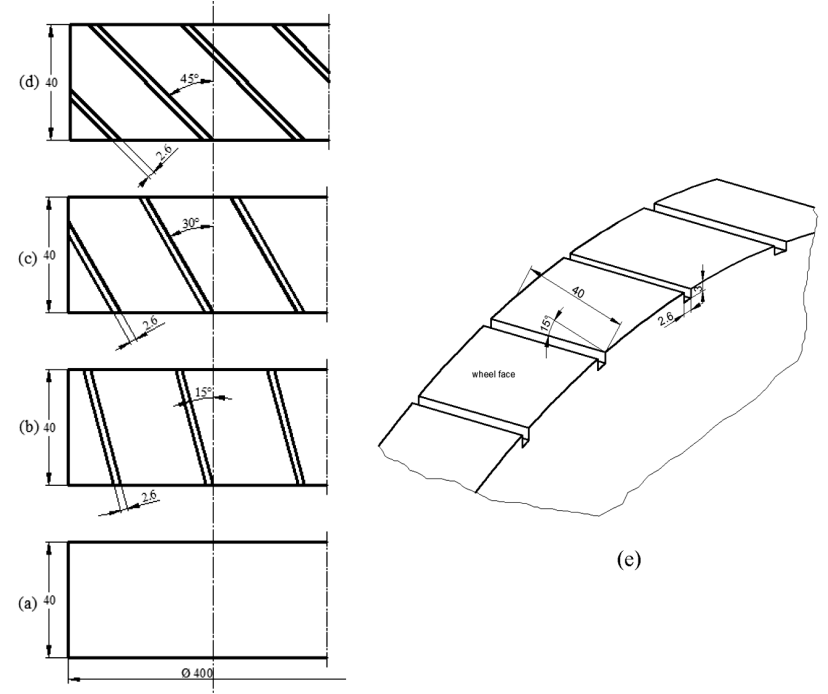

Figure 1: Dimensions of the grinding wheels: a) FSGW, b) HGGW $15^{\circ}$, c) $\mathrm{HGGW} 30^{\circ}$ and d) HGGW $45^{\circ}$ (dimensions in milimeters), e) isometric perspective of $\mathrm{HGGW} 15^{\circ}$

Slika 1: Dimenzije brusnih kolutov: a) FSGW, b) HGGW $15^{\circ}$, c) HGGW $30^{\circ}$ in d) HGGW $45^{\circ}$ (dimenzije v milimetrih), e) izometrična perspektiva $\mathrm{HGGW} 15^{\circ}$ 


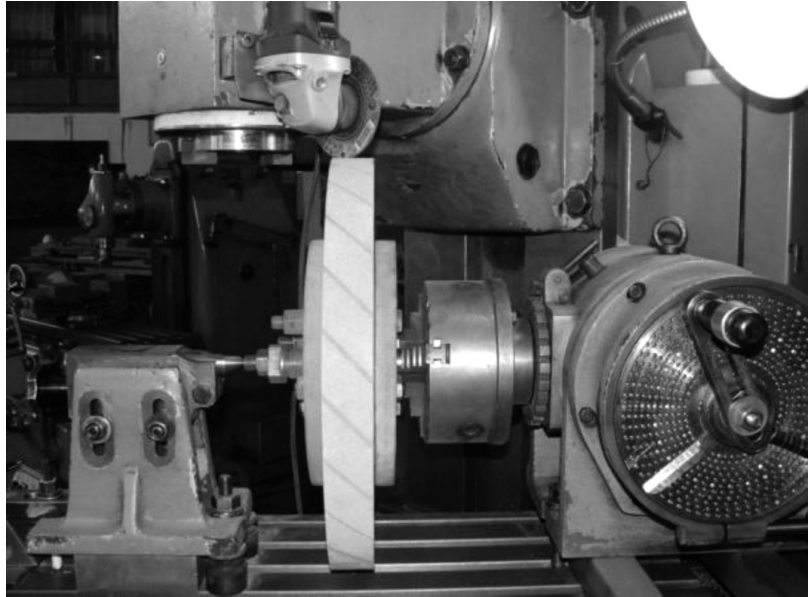

Figure 2: Forming of helical grooves on a grinding wheel with a cutoff disc

Slika 2: Izdelava vijačnega utora na brusnem kolutu $\mathrm{z}$ rezalno ploščico

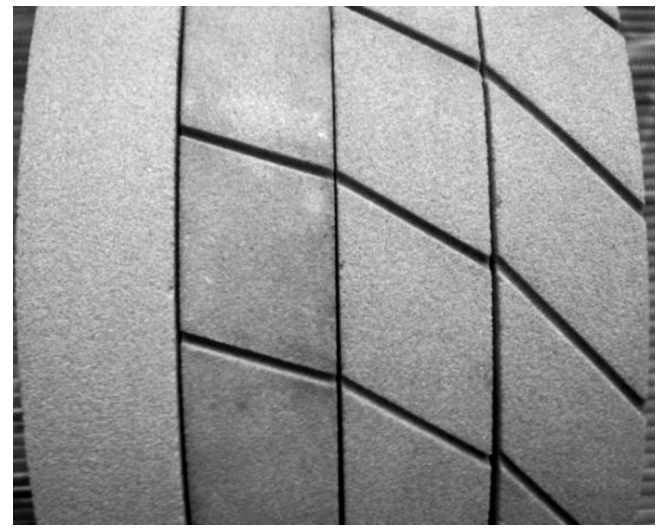

Figure 3: Photograph of FSGW and HGGWs Slika 3: Posnetek FSGW in HGGW

the conventional grinding wheel and helically grooved grinding wheels (HGGWs).
The helical grooves at the angles of $15^{\circ}, 30^{\circ}$, and $45^{\circ}$ on the circumference of the grinding wheels were cut in with a universal milling machine using a cut-off disc in the angle grinder. The HGGWs were made by cutting radial grooves with a helical profile. These grinding wheels consisted of 24 equal grooves on the circumference of a grinding wheel. The width and depth of each groove was $2.6 \mathrm{~mm}$ and $3 \mathrm{~mm}$, respectively. The forming of the helical grooves on a grinding wheel with a cut-off disc is shown in Figure 2. FSGW and HGGWs with different helix angles are shown in Figure 3. ${ }^{21}$

\subsection{Materials, grinding parameters and the measure- ment procedure}

The materials used in this study were AISI 1050, AISI 4140, and AISI 7131; the chemical compositions and hardness values of the materials are listed in Table $\mathbf{1}$ and the dimensions of the workpieces are shown in Figure 4. Grinding-test bar specimens with a diameter 39 $\mathrm{mm}$ and length $170 \mathrm{~mm}$ were prepared by turning them directly from the as-received materials.

The grinding conditions and dimensions of the specimens were the same for both methods. In the grinding experiments, a horizontal spindle-type cylindrical-grinding machine with aluminum-oxide grinding wheels with dimensions of $400 \mathrm{~mm} \times 40 \mathrm{~mm} \times 127 \mathrm{~mm}$ and a constant wheel speed of $1570 \mathrm{r} / \mathrm{min}$ was used. Furthermore, these elements were common. $60-\mathrm{K}-6-\mathrm{V}$ indicates a wheel grain size of 60 , hardness $\mathrm{K}$, structure 6 and a vitrified bond. The selection was based on a wide industrial application of grinding wheels. Before each grinding experiment, the grinding wheel was dressed using a single-point diamond dresser to produce a sharp, clean wheel surface. During the grinding process, a watersoluble metalworking fluid diluted to $1: 5$ was supplied to the grinding zone, and the coolant flow rate from the outlet was $8 \mathrm{~L} / \mathrm{min}$. During all the experiments, the

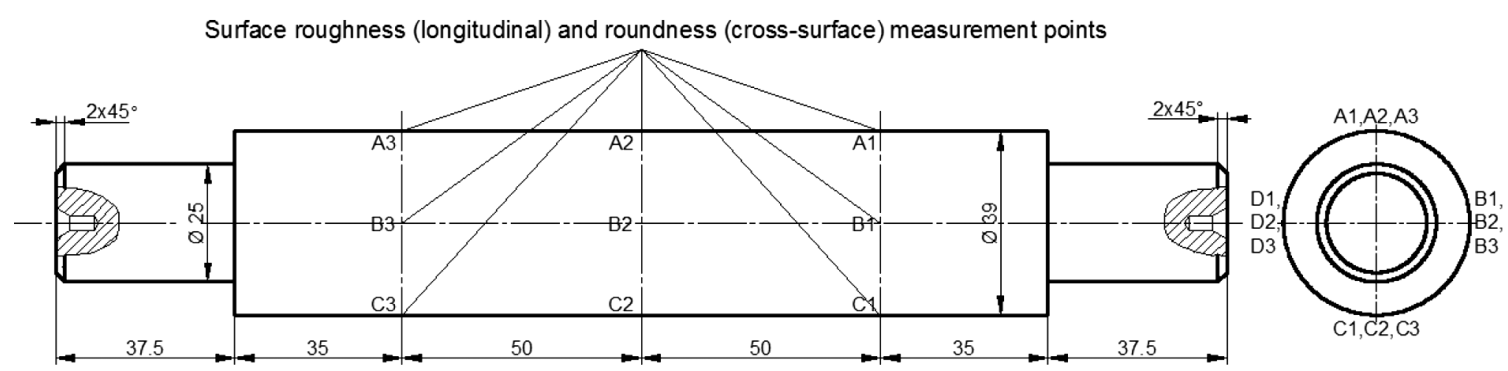

Figure 4: Dimensions and measurement points for the surface roughness and roundness of a grinding workpiece used in the experiments Slika 4: Dimenzije in točke merjenja hrapavosti površine in okroglosti na obdelovancu, uporabljenem pri preizkusih

Table 1: Chemical compositions $(w / \%)$ and hardness of the materials used in the experiment

Tabela 1: Kemijske sestave $(w / \%)$ in trdote materialov, uporabljenih pri preizkusih

\begin{tabular}{|c|c|c|c|c|c|c|c|c|}
\hline Materials & $\mathrm{C}$ & $\mathrm{Si}$ & $\mathrm{Mn}$ & $\mathrm{P}$ & $\mathrm{S}$ & $\mathrm{Cr}$ & Mo & Hardness (HRB) \\
\hline AISI 1050 & $0.47-0.55$ & $0.15-0.35$ & $0.60-0.90$ & 0.04 & 0.05 & - & - & 96 \\
\hline AISI 4140 & $0.35-0.44$ & $0.15-0.40$ & $0.60-0.90$ & 0.035 & 0.035 & $0.80-1.10$ & - & 99 \\
\hline AISI 7131 & $0.14-0.19$ & $0.15-0.40$ & $1.00-1.30$ & 0.035 & 0.035 & $0.80-1.10$ & $0.15-0.25$ & 115 \\
\hline
\end{tabular}




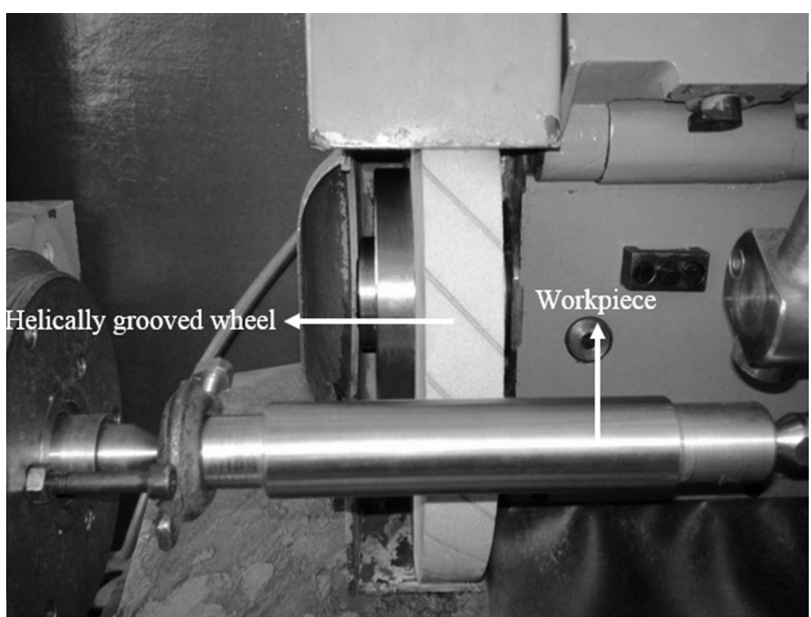

Figure 5: Experimental set-up

Slika 5: Eksperimentalni sestav

grinding length $(170 \mathrm{~mm})$, workpiece diameter $(39 \mathrm{~mm})$, depth of cut $(10 \mu \mathrm{m})$ and feed rate $(1.57 \mathrm{~mm} / \mathrm{r})$ were used. In addition, each work material was ground for 5 min before measuring the surface roughness and roundness error. The experimental set-up is shown in Figure 5.

The measurement points for the surface roughness and waviness of the work material are shown in Figure 4. Each test specimen was measured on 12 different points (A1, A2, A3), (B1, B2, B3), (C1, C2, C3), and (D1, D2, D3) for the surface roughness. For the roundness, each test specimen was measured on three points $(1,2$, and 3$)$. In this study, the surface roughness $\left(R_{\mathrm{a}}\right.$, the arithmetic average) of each machined workpiece was measured using a surface roughness tester (Mahr Perthen) with a $4 \mathrm{~mm}$ cut-off length. In addition, a recorder that transfers the obtained values onto a graphic was also used. The roundness was measured with a round test instrument (Mitutoyo RA-114) in the same locations.

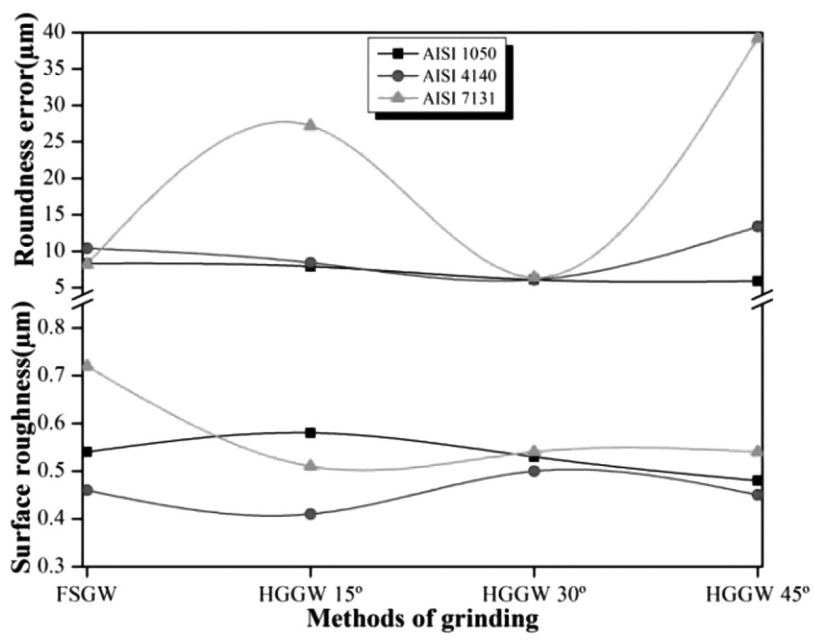

Figure 6: Ground surface roughness and roundness for FSGW and HGGWs

Slika 6: Brušena površinska hrapavost in okroglost pri FSGW in HGGW

\section{RESULTS AND DISCUSSION}

The experimental results for the surface roughness of three steels at the same grinding conditions using both FSGW and HGGWs are shown in Figure 6. Each surface-roughness value was obtained by averaging 12 measurements. One of these 12 measurements was used to represent the surface roughness of the ground part. It is obvious that both the material type and the grinding method have an effect on the surface roughness. The highest surface roughness was obtained for the AISI 7131 steel ground with FSGW. The effect of the material type on the surface roughness is often attributed to the difference in the hardness of different materials. ${ }^{5}$

Generally, the surface roughness obtained with HGGWs is better than that obtained with FSGW. It is apparent that $\mathrm{HGGW} 45^{\circ}$ gives better surface finishes of the three steels than FSGW. As the grooves on the circumference of a grinding wheel decrease the grinding force, temperature ${ }^{15}$ and contact length between the workpiece and the grinding wheel, and enough cutting fluid is being delivered to the wheel-workpiece interface, ${ }^{13}$ it is, consequently, expected that HGGWs are better in terms of the ground-surface quality. ${ }^{21,22}$

Figures 6 and 7 show a comparison of the roundness of the ground workpieces produced with FSGW and HGGWs under the same grinding conditions. It is obvious that both the material type and the grinding method have an effect on the roundness. Generally, the roundness obtained with HGGWs is better than that obtained with FSGW. When the roundness values obtained

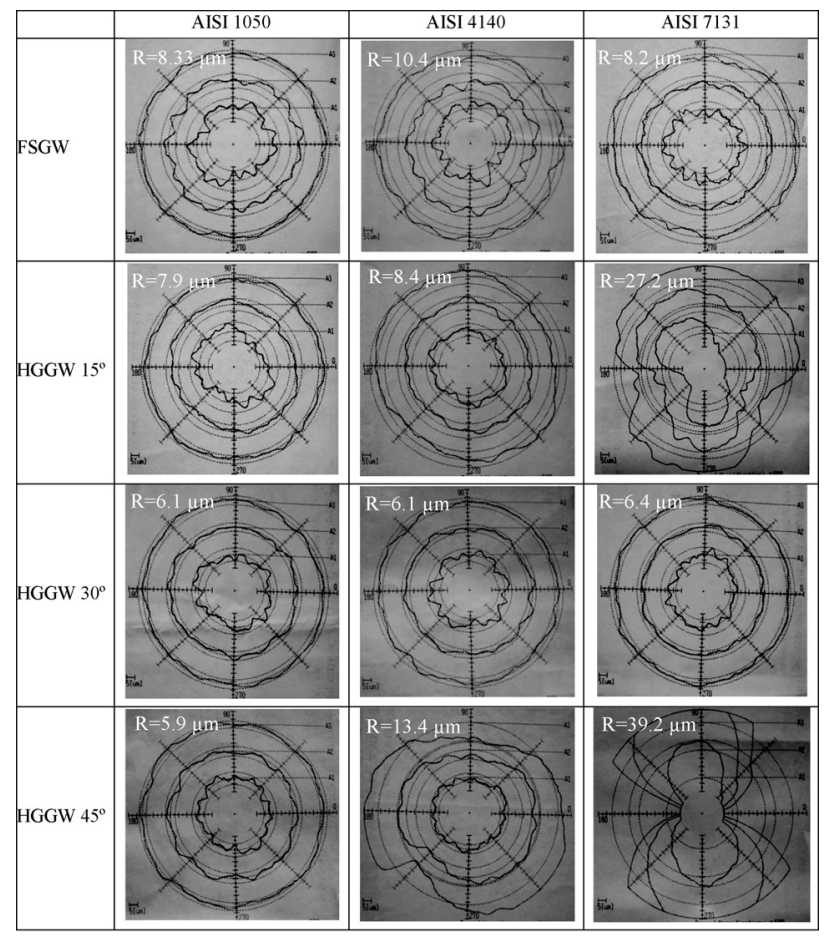

Figure 7: Profiles of the ground surfaces produced with FSGW and HGGWs

Slika 7: Profil brušenih površin pri FSGW in HGGW 
with FSGW and HGGWs are compared, it is clearly seen that the roundness error increased for the AISI 7131 steel, while the AISI 1050 and AISI 4140 steels behave in an identical manner during the grinding in view of the roundness error. For comparison, the roundness values of the three steels ground in the FSGW and HGGW processes are shown in Figure 7. Among the HGGWs, HGGW $30^{\circ}$ seemed to generate the lowest roundness. Consequently, the grinding with helically grooved wheels (HGGW $15^{\circ}$ and HGGW $30^{\circ}$ ) increases the roundness quality, while the AISI 7131 steel showed conflicting behavior, namely, the roundness increased for the this material.

The AISI 7131 steel and HGGW $45^{\circ}$ showed unexpected behavior; namely, the surface roughness and roundness increased for this material. This is explained with the segmentation of the grinding wheel, reducing the number of static and kinematic cutting edges and, hence, the rubbing regime, which is one of the important mechanisms for improving the surface roughness. Additionally, the uncut-chip thickness increases with the decrease in the kinematic cutting edges. Tawakoli and Azarhoushang ${ }^{20}$ suggested the following relation (Equation (1)) involving $R_{\mathrm{t}}$ (the distance between the highest peak and the deepest valley of the profile of the total evaluation length or, in other words, the total height of the profile) and the uncut-chip thickness $h_{\mathrm{cu}}$ :

$$
R_{t} \infty \frac{h_{\mathrm{cu}}^{4 / 3}}{a_{\mathrm{e}}^{1 / 3}} \approx\left(\frac{v_{\mathrm{ft}}}{v_{\mathrm{c}}} \frac{1}{C_{\mathrm{kin}} r \sqrt{d_{\mathrm{s}}}}\right)^{2 / 3}
$$

where $h_{\mathrm{cu}}$ is the uncut-chip thickness, $a_{\mathrm{e}}$ is the depth of cut, $v_{\mathrm{ft}}$ is the feed speed, $v_{\mathrm{c}}$ is the cutting speed, $d_{\mathrm{s}}$ is the wheel diameter, $r$ is the grain-cutting-point shape factor, and $C_{\text {kin }}$ is the kinematic cutting-edge density.

\section{CONCLUSIONS}

In this study, grinding operations of a flat-surface wheel and helically grooved wheels were performed on three different steels (AISI 1050, AISI 4140 and AISI 7131) under the same grinding conditions, except for the grinding-wheel profile. The surface roughness and roundness obtained from these processes were demonstrated. Both the material type and the grinding method have an effect on the surface roughness and roundness. The experimental results show that, generally, the surface roughness and roundness obtained with a helically grooved grinding wheel are better than in the case of conventional grinding. Additionally, among the helically grooved wheels, $\mathrm{HGGW} 30^{\circ}$ seemed to generate a lower roundness than the other two HGGWs and FSGW. Consequently, grinding with helically grooved wheels (HGGW $15^{\circ}$ and $\mathrm{HGGW} 30^{\circ}$ ) increased the surface roughness and roundness, while the AISI 7131 steel showed conflicting behavior, namely, the roundness of this material was increased.

\section{REFERENCES}

${ }^{1}$ M. Ubartas, V. Ostaševičius, S. Samper, V. Jūrènas, R. Daukševičius, Experimental investigation of vibrational drilling, Mechanika, 17 (2011) 4, 368-373, doi:10.5755/j01.mech.17.4.563

${ }^{2}$ X. Tian, J. P. Huissoon, Q. Xu, B. Peng, Dimensional error analysis and its intelligent pre-compensation in cnc grinding, International Journal of Advanced Manufacturing Technology, 36 (2008) 1-2, 28-33, doi:10.1007/s00170-006-0813-y

${ }^{3}$ M. Chandrasekaran, M. Muralidhar, C. M. Krishna, U. S. Dixit, Application of soft computing techniques in machining performance prediction and optimization: a literature review, International Journal of Advanced Manufacturing Technology, 46 (2010) 5-8, 445-464, doi:10.1007/s00170-009-2104-X

${ }^{4}$ P. L. Tso, S. Y. Yang, The compensation of geometrical errors on forming grinding, Journal of Materials Processing Technology, 73 (1998) 1-3, 82-88, doi:10.1016/S0924-0136(97)00216-1

${ }^{5}$ M. Gavas, İ. Karacan, E. Kaya, A novel method to improve surface quality in cylindrical grinding, Experimental Techniques, 35 (2011) 1, 26-32, doi:10.1111/j.1747-1567.2009.00575.x

${ }^{6}$ F. Holesovsky, M. Hrala, Integrity of ground cylindrical surface, Journal of Materials Processing Technology, 153-154 (1999), 714-721, doi:10.1016/j.jmatprotec.2004.04.180

${ }^{7}$ U. Köklü, Optimisation of machining parameters in interrupted cylindrical grinding using the Grey-based Taguchi method, International Journal of Computer Integrated Manufacturing, 26 (2013) 8, 696-702, doi:10.1080/0951192X.2012.749537

${ }^{8}$ M. Kurt, U. Köklü, Minimization of the shape error in the interrupted grinding process by using Taguchi method, Mechanika, 18 (2012) 6 , 677-682, doi:10.5755/j01.mech.18.6.3163

${ }^{9}$ J. F. G. Oliveira, A. C. Bottene, T. V. França, A novel dressing technique for texturing of ground surfaces, CIRP Annals - Manufacturing Technology, 59 (2010), 361-364, doi:10.1016/j.cirp.2010.03.119

${ }^{10}$ K. Nakayama, J. Takagi, T. Abe, Grinding wheel with helical grooves - an attempt to improve the grinding performance, CIRP Annals - Manufacturing Technology, 25 (1977) 1, 133-138

${ }^{11}$ K. W. Lee, P. K. Wong, J. H. Zhang, Study on the grinding of advanced ceramics with slotted diamond wheels, Journal of Materials Processing Technology, 100 (2000) 1-3, 230-235, doi:10.1016/S0924-0136(00)00403-9

${ }^{12}$ X. Fan, M. H. Miller, Force analysis for grinding with segmental wheels, Machining Science and Technology, 10 (2006) 4, 435-455, doi:10.1080/10910340600996142

${ }^{13}$ J. D. Kim, Y. H. Kang, D. X. Jin, Y. S. Lee, Development of discontinuous grinding wheel with multi-porous grooves, International Journal of Machine Tools and Manufacture, 37 (1997) 11, 1611-1624, doi:10.1016/S0890-6955(97)00005-9

${ }^{14}$ D. X. Jin, Z. Meng, Research for discontinuous grinding wheel with multi porous grooves, Key Engineering Materials, 259-260 (2004), 117-121, doi:10.4028/www.scientific.net/KEM.259-260.117

${ }^{15} \mathrm{~S}$. Shaji, V. Radhakrishnan, Application of solid lubricants in grinding: investigations on graphite sandwiched grinding wheels, Machining Science and Technology, 7 (2003) 1, 137-155, doi:10.1081/MST120018959

${ }^{16}$ B. Zhang, Helical scan grinding of brittle and ductile materials, Journal of Materials Processing Technology, 91 (1999) 1-3, 196-205, doi:10.1016/S0924-0136(98)00420-8

${ }^{17}$ B. Zhang, T. Uematsu, Surface generation mechanism in helical scan grinding: an analytical study, Journal of Materials Processing Technology, 91 (1999) 1-3, 206-214, doi:10.1016/S0924-0136(98) 00415-4

${ }^{18}$ T. Nguyen, L. C. Zhang, Performance of a new segmented grinding wheel system, International Journal of Machine Tools \& Manufacture, 49 (2009) 3-4, 291-296, doi:10.1016/j.ijmachtools.2008.10.015

${ }^{19}$ J. S. Kwak, M. K. Ha, Force modelling and machining characteristics of the intermittent grinding wheels, KSME International Journal, 15 (2001) 3, 351-356 
${ }^{20}$ T. Tawakoli, B. Azarhoushang, Intermittent grinding of ceramic matrix composites (CMCs) utilizing a developed segmented wheel, International Journal of Machine Tools \& Manufacture, 51 (2011) 2, 112-119, doi:10.1016/j.ijmachtools.2010.11.002

${ }^{21}$ M. Kina, Effect of Various Helical Angled Grinding Wheel to Surface Roughness and Roundness in Grinding of Cylindrical Surfaces, MSc Thesis, Kutahya, 2011

${ }^{22}$ U. Köklü, Grinding with helically grooved wheels, Proceedings of the Institution of Mechanical Engineers, Part E: Journal of Process Mechanical Engineering, 228 (2014) 1, 33-42, doi:10.1177/ 0954408912470775 